\title{
Antiphospholipid syndrome and retinal vein occlusion in adults
}

R.M. Maaroufi, ${ }^{1,3}$ R. Hamdi, ${ }^{2}$ N. Jmili, ${ }^{3}$ M. Ghorbal, ${ }^{2}$ F. Bel Hadj Hamida ${ }^{2}$ and T. Mahjoub ${ }^{3}$

$$
\begin{aligned}
& \text { متلازمة مضادات الفوسفوليبيد وانسداد الوريد الشبكي بين البالغين }
\end{aligned}
$$

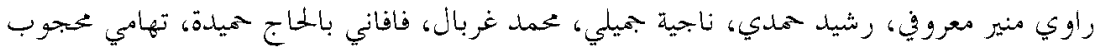

الحلاحسة: قدل يكون لأضداد الفو سفوليبيدات دور هام في إحداث انسداد الأوعية الثبكية، وقد قام البـاحثون باستقصاء

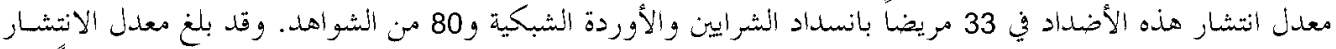

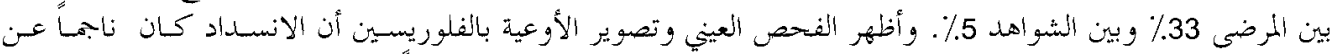

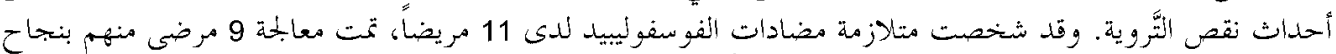

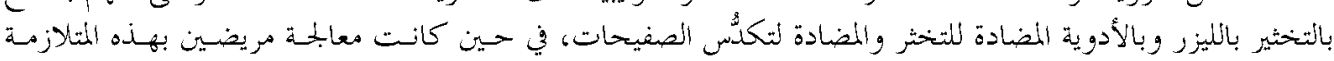

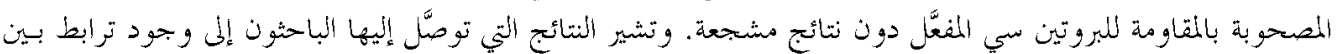

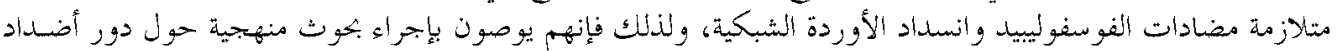

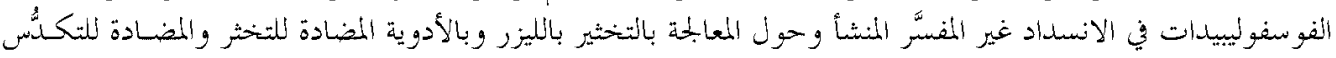
على المندى الطويل.

ABSTRACT Antiphospholipid antibodies may play an important role in the pathogenesis of retinal vascular occlusions; therefore, we investigated the prevalence among 33 patients with retinal vein and artery occlusions and 80 controls. Prevalence was $33 \%$ and $5 \%$ respectively. Ophthalmic examination and fluorescein angiography showed that occlusions were due to ischaemic events. The 11 patients were diagnosed with antiphospholipid syndrome: 9 patients were treated successfully with laser photocoagulation and anticoagulant and anti-aggregant therapy. Two patients with antiphospholipid antibodies associated with resistance to activated protein $\mathrm{C}$ had unfavourable outcomes. Our results suggest a correlation between antiphospholipid syndrome and retinal vein occlusions; we recommend a systematic search for antiphospholipid antibodies in occlusions of unexplained origin and laser photocoagulation treatment and long-term oral anticoagulant and anti-aggregant therapy.

\section{Le syndrome des antiphospholipides et l'occlusion veineuse rétinienne chez l'adulte}

RÉSUMÉ Les antiphospholipides peuvent jouer un rôle important dans la pathogenèse des occlusions vasculaires rétiniennes; nous avons donc étudié la prévalence chez 33 patients atteints d'occlusions veineuses et artérielles rétiniennes et 80 témoins. La prévalence s'élevait à $33 \%$ et $5 \%$ respectivement. L'examen ophtalmologique et l'angiographie fluorescéinique ont montré que les occlusions étaient dues à des événements ischémiques. Le syndrome des antiphospholipides a été diagnostiqué chez 11 patients : neuf patients ont été traités avec succès par photocoagulation au laser associant un traitement anticoagulant et antiagrégant. Deux patients présentant des anticorps antiphospholipides associés à une résistance à la protéine $\mathrm{C}$ activée ont eu une issue défavorable. Nos résultats semblent indiquer une corrélation entre le syndrome des antiphospholipides et les occlusions veineuses rétiniennes ; nous recommandons une recherche systématique des anticorps antiphospholipides dans les occlusions d'origine inexpliquée et un traitement par photocoagulation au laser et un traitement anticoagulant et antiagrégant de longue durée.

${ }^{1}$ Higher Institute of Biotechnology, Monastir, Tunisia.

${ }^{2}$ Department of Ophthalmology, Farhat Hached University Hospital, Sousse, Tunisia.

${ }^{3}$ Haematology and Autoimmune Diseases Unit, Faculty of Pharmacy, University of Monastir, Tunisia.

Received: 29/04/03; accepted: 23/12/03

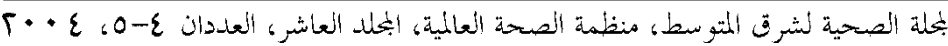




\section{Introduction}

Antiphospholipid antibodies are a heterogeneous family of antibodies directed to plasma protein co-factors bound to anionic phospholipids. The clinical relevance of antiphospholipid antibodies derives from the association with venous and arterial thrombosis, recurrent abortions and thrombocytopenia [1]. Antiphospholipid antibodies include lupus anticoagulant and anticardiolipin antibodies [2,3]. This association has been termed the antiphospholipid syndrome (APS), which may occur alone (primary APS) or in the setting of an underlying disease, mainly systemic lupus erythematosus (SLE) [4-7].

Hypercoagulable states, including a variety of disorders such as reduced levels of antithrombin, protein $\mathrm{C}$, protein S or presence of antiphospholipid antibodies, are common in patients with retinal vein occlusions and may contribute to the etiology of the disease [8].

In particular, retinal vascular occlusions in patients with primary APS, i.e. with antiphospholipid antibodies but with no other conventional risk factors, result from thrombus formation in either the retinal vein, artery or both [9-12].

We investigated the prevalence of antiphospholipid antibodies in a group of 33 patients with retinal vein occlusion and in 80 normal controls. Whether antiphospholipid antibodies included lupus anticoagulant, anticardiolipin antibodies or both was also investigated. This study aimed to assess the relationship between the occurrence of antiphospholipid antibodies in primary APS and occlusive retinal vascular events.

\section{Methods}

From January-December 2002, 33 patients (14 men and 19 women, mean age 37 years and age range 22-63 years) with retinal vein (29) or artery (4) occlusions were selected from the Department of Ophthalmology of the Farhat Hached Hospital, Sousse, Tunisia. Exclusion criteria were diabetes, hypertension, hypercholesterolaemia and hypertriglyceridaemia. We used 80 normal controls from among healthy blood donors at the Centre Régional de Transfusion Sanguine of Farhat Hached Hospital. Informed consent was obtained from patients and controls prior to their participation in our study.

Patients were examined clinically. A questionnaire was administered before patients underwent ophthalmologic examination and retinal flourescein angiography.

Biological assays for cholesterol and triglycerides were performed. Antinuclear antibodies were investigated with standardized enzyme-linked immunosorbent assay (ELISA).

Screening studies for APS included assays for anticardiolipin antibodies and lupus anticoagulant. Anticardiolipin antibodies (IgG and IgM isotypes) were also determined by ELISA assay (Diagnostica Stago, Asnières, France). Lupus anticoagulant was assayed with clotting techniques. Anticardiolipin antibodies and lupus anticoagulant were measured 8 weeks later.

We also screened for abnormalities in the coagulation process. Activated partial thromboplastin time and kaolin clotting time tests were performed. The levels of protein $\mathrm{C}$ and protein $\mathrm{S}$ were determined by ELISA assay (Diagnostica Stago, Asnières, France). Antithrombin III level was evaluated by colorimetric assay (Asserachrom, Diagnostica Stago, Asnières, France) and levels of factors VIIIc and XI were determined with clotting assays (Diagnostica Stago, Asnières, France). Factor V Leiden was investigated through the evaluation of the activated protein $\mathrm{C}$-sensitivity ratio

بلملة الصحية لشرق المتو سط، منظمة الصحة العالمية، البحلد العانر، العددان ع-0، ع + •؟ 
(Accelerimat, bioMérieux, Marcy l’Etoile, France). Genetic analysis of factor V Leiden mutation was performed as previously described [13].

Chi-squared test was used to compare the patient and control groups.

\section{Results}

All patients underwent fundus fluorescein angiography and ophthalmologic examination. Almost all suffered from retinal vein occlusions (29 of 33 patients); the occlusive events primarily involved the central (9 patients) and the temporal (8 patients) veins. Only 4 patients had artery occlusions (Table 1). The prevalence of antiphospholipid antibodies in the study group was 33\% (11 of 33 patients) while in the control group it was $5 \%$ (4 of 80 ). This difference was statistically significant $\left(\chi^{2}=16.29, P\right.$ $<0.001)$.

All patients with antiphospholipid antibodies had retinal vein occlusions, particularly temporal vein occlusions (5 of 11 patients). Only 1 patient with antiphospholipid antibodies had a central vein occlusion. None of the patients with artery occlusions tested positive for any of the assays.

In the study group 2 patients were positive for IgG-anticardiolipin antibodies, 3 patients for IgM-anticardiolipin antibodies and 1 patient for both isotypes IgG and IgM-anticardiolipin antibodies. The 5 remaining patients were negative for anticardiolipin antibodies but showed positivity for lupus anticoagulant (Table 1). Two patients had associated protein $\mathrm{C}$ resistance. All patients were negative for antinuclear antibodies. No deficiency in antithrombin III, protein $\mathrm{C}$ or protein $\mathrm{S}$ was found. Factors VIII and XI levels were within normal.

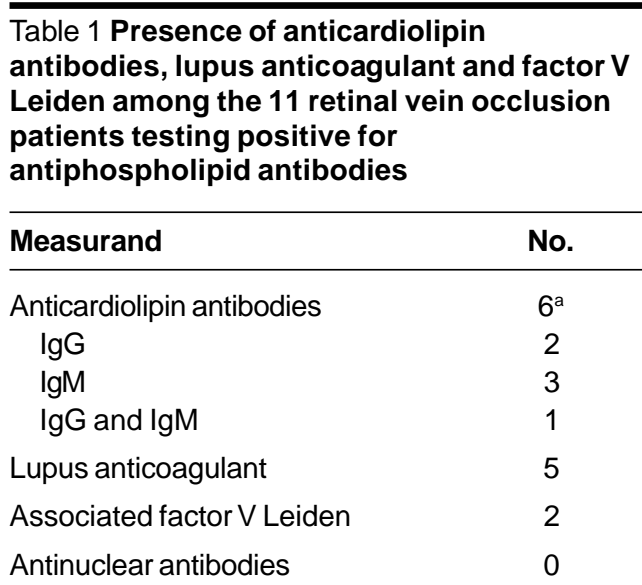

\section{Discussion}

The etiology of retinal vein occlusion is still not well understood although thrombosis does occur histologically. Hypercoagulable states seem to be common in patients with retinal vein occlusions [8]. The presence of antiphospholipid antibodies in APS is likely to generate a hypercoagulable state such as to cause thrombosis to occur [1]. It is known that antiphospholipid antibodies impair the metabolism of arachidonic acid in endothelial cells and platelets causing the inhibition of prostaglandin I2 (PGI2) production by endothelial cells and activation of platelets through stimulating thromboxane $\mathrm{A} 2$ generation $[14,15]$. Furthermore, antiphospholipid antibodies inhibit protein C and protein S, preventing coagulation factors Va and VIIa from inactivation [16,17]. Among other implications of the antiphospholipid antibodies syndrome is an increase in tissular factor release and in plasminogen activator inhibitor level. These implications could make it possible for thrombosis to occur even in veins or arteries, although

البحلة الصحية لشرق المتو سط، منظمة الصحة العالمية، البحلد العاشر، العددان ع-0، ع • • 
most vascular occlusions (81\%) were found to affect venous vessels in a recent study [11].

Elevated levels of anticardiolipin antibodies have recently been associated with acute vascular occlusions of the eye although their role remains unclear [12,1821]. Of 33 patients with retinal vascular occlusions, 11 (33\%) were diagnosed with APS. They possibly had primary APS without any underlying immune disorder like lupus erythematosus because each was negative for antinuclear antibodies. None of our patients, however, was investigated for other possible immune disorders. It is noteworthy that 9 of the 11 patients had no other conventional risk for thrombosis, whereas the presence of antiphospholipid antibodies was associated with resistance to activated protein $\mathrm{C}$ for the 2 others.

The high prevalence of antiphospholipid antibodies in our study indicates that antiphospholipid antibodies may play an important role in the pathogenesis of retinal vein occlusions and thus may represent a risk factor of importance in the etiology of the disease. This may also suggest the necessity of screening for antiphospholipid antibodies in such patients. Furthermore, in our study group, the prevalence of antiphospholipid antibodies seemed to be related to retinal vein occlusions mainly involving the temporal vein and not to artery vein occlusions. This warrants further investigation. It should be noted that the role of antiphospholipid antibodies in retinal vein occlusion is still controversial. Our results provide more support for such a role of antiphospholipid antibodies in the pathogenesis of this disease.

Our results (33\% prevalence of antiphospholipid antibodies in patients with retinal vascular occlusions) were dissimilar from studies that identified lower preva- lences of $5 \%, 7.5 \%$ and $9 \%$ respectively among patients with primary APS $[18,9,12]$; however, in the two latter studies, these levels could have been $22.5 \%$ and $22 \%$ if antiphospholipid antibodies were associated with lupus erythematosus, the elevation of circulating immune complexes or complement deficiencies respectively $[9,12]$. Our results nevertheless indicate higher prevalence of antiphospholipid antibodies in retinal vein occlusions than the results of these authors. It should be noted that our study is the first of its kind in Tunisia and that a cohort study among the Tunisian population is needed.

In our study, all patients with antiphospholipid antibodies except 2 were treated successfully with laser photocoagulation and anticoagulant and anti-aggregant therapy (acenocoumarol, to get the patient's international normalized ratio to 2-4, and lysine acetylsalicylate, $250 \mathrm{mg}$ per day) [22]. The 2 exceptions had associated resistance to activated protein $\mathrm{C}$ with the presence of antiphospholipid antibodies and experienced unfavourable developments. One had an occlusive event in the second eye and the other became blind even though therapy was provided.

In retinal vascular occlusions of unexplained origin, antiphospholipid antibodies may play an important role in pathogenesis. Detecting these antibodies in the serum of patients with retinal vascular occlusions may help to determine the appropriate treatment. The high prevalence of anticardiolipin antibodies in these patients who are free of conventional risk factors leads us to recommend a systematic search for specific antiphospholipid antibodies for them. This should be part of a treatment combining laser photocoagulation, and long-term anti-aggregant and oral anticoagulant therapy [19].

بلملة الصحية لشرق المتو سط، منظمة الصحة العالمية، البحلد العانر، العددان ع-0، ع + •؟ 


\section{References}

1. De Groot PG, Oosting JD, Derksen RH. Antiphospholipid antibodies: specificity and pathophysiology. Balliere's clinical haematology, 1993, 6:691-709.

2. Exner T, Triplett DA. Lupus anticoagulants: characteristics, methods of laboratory detection and some clinical associations. In: Harris EN et al., eds. Phospholipid binding antibodies. Boca Raton, Florida, CRC Press, 1991:14158.

3. Loizou S et al. Measurement of anticardiolipin antibodies by an enzyme-linked immunosorbent assay (ELISA): standardization and quantitation of results. Clinical and experimental immunology, 1985, 62:738-45.

4. Harris EN et al. Clinical and serological features of the antiphospholipid syndrome (APS). British journal of rheumatology, 1987, 26:19.

5. Alarcon-Segovia D, Sanchez-Guerrero J. Primary antiphospholipid syndrome. Journal of rheumatology, 1989, 16:4828.

6. Italian registry of antiphospholipid antibodies (IR-APA). Thrombosis and thrombocytopenia in antiphospholipid syndrome (idiopathic and secondary to SLE): first report from the Italian registry. Haematologica, 1993, 78:313-8.

7. Khamashta MA. Management of thrombosis in the antiphospholipid syndrome. Lupus, 1996, 5(5):463-6.

8. Abu El-Asrar AM et al. Hypercoagulable states in patients with retinal vein occlusion. Documenta ophthalmologica, 1998, 95(2):133-43.

9. Cobo-Soriano R et al. Antiphospholipid antibodies and retinal thrombosis in patients without risk factors: a prospective case-control study. American journal of ophthalmology, 1999, 128(6):725-32.
10. Coniglio $\mathrm{M}$ et al. Antiphospholipid antibodies are not an uncommon feature in retinal venous occlusions. Thrombosis research, 1996, 83(2):183-8.

11. Demirci FY et al. Ocular involvement in primary antiphospholipid syndrome. Ocular involvement in primary APS. International ophthalmology, 1998, 22(6):323-9.

12. Cobo Soriano $R$ et al. Trombosis retiniana en pacientes jóvenes. Aspectos inmunológicos y clínicos. [Retinal thrombosis in young patients. Immunological and clinical aspects.] Archivos de la Sociedad Española de Oftalmología, 2001, 76(11):641.

13. Ridker PM et al. Mutation in the gene coding for coagulation factor $\mathrm{V}$ and the risk of myocardial infarction, stroke and venous thrombosis in apparently healthy men. New England journal of medicine, 1995, 332:912-7.

14. Lellouche $\mathrm{F}$ et al. Influence of thromboxane/prostacyclin biosynthesis in patients with lupus anticoagulant. Blood, 1991, 78:2894-9.

15. Karmochkine $M$ et al. The effect of sera with antiphospholipid antibodies on endothelial cell procoagulant activity is dependent upon the charge of the phospholipids against which they are directed. Thrombosis research, 1994, 74:435-40.

16. Cariou R et al. Effect of lupus anticoagulant on antithrombogenic properties of endothelial cells. Inhibition of thrombomodulin-dependent protein $\mathrm{C}$ activation. Thrombosis and haemostasis, 1988, 60:54-8.

17. Smirnov MD et al. On the role of phosphatidylethanolamine in the inhibition of protein $\mathrm{C}$ activity by antiphospholipid antibodies. Journal of clinical investigation, 1995, 95:309-18.

البحلة إلصحية لشرق المتو سط، منظمة الصحة العمامية، البحلد العاشر، العلدان ع-ه، ع + • 
18. Glacet-Bernard A et al. Antiphospholipid antibodies in retinal vascular occlusions. A prospective study of 75 patients. Archives of ophthalmology, 1994, 112(6):790-5.

19. Wiechens B et al. Primary antiphospholipid antibody syndrome and retinal occlusive vasculopathy. American journal of ophthalmology, 1997, 123(6): 848-50.

20. Ermakova NA et al. Rol' antifosfolipidnykh antitel $v$ okkliuzii sosudov setchatki pri razlichnykh sosudistykh zabolevaniiakh glaza. [Role of antiphospholipid antibodies in occlusion of retinal vessels in various vascular eye diseases.] Vestnik oftalmologii, 2002, 118(2):29-32.

21. Carbone $\mathrm{J}$ et al. Antiphospholipid antibodies: a risk factor for occlusive retinal vascular disorders. Comparison with ocular inflammatory diseases. Journal of rheumatology, 2001, 28(11):2437-41.

22. Dunn JP et al. Antiphospholipid antibodies and retinal vascular disease. Lupus, 1996, 5(4):313-22.

\section{Correction}

Screening for congenital hypothyroidism in the Islamic Republic of Iran: strategies, obstacles and future perspectives A. Ordookhani, P. Mirmiran, R. Hajipour, M. Hedayati and F. Azizi. Eastern Mediterranean Health Journal, 2002, Vol. 8 Nos 4/5, pages 480-9.

The title of the French abstract should read:

Dépistage de l'hypothyrö̈die congénitale en République islamique d'Iran : stratégies, obstacles et perspectives futures and hypothyroïdie should replace hyperthyroïdie throughout the text of the abstract.

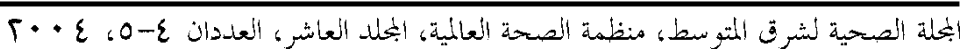

